\title{
Å være til stede på en god måte: \\ Tegnspråktolkers refleksjoner rundt å jobbe i Tolk på arbeidsplass-ordningen
}

\author{
Sarah Beth Evans-Jordan
}

Sarah Evans-Jordan Language Services

sarah.evans.jordan@gmail.com

\section{Keywords:}

deaf

Norwegian Sign Language

sign language interpreting

interpreting in the public sector

workplace interpreting

staff interpreting

itinerant interpreting

interpreting in Norway 


\section{Abstract}

This article describes some of the findings of a study whose aim was to shed light upon Norway's Workplace Interpreting Scheme (TPA), which gives deaf sign language users the right to interpretation in the workplace. The study consists of qualitative interviews with a sample of interpreters who work in the scheme in its various forms. At issue was how interpreters experience being an interpreter in these settings, with the research question: How do professional, ethical, and practical aspects of workplace interpreting influence interpreters' reflections on questions of language and role?

An earlier evaluation of the Workplace Interpreting Scheme (ECON, 2004) asked deaf and hearing users of the scheme whether they thought the scheme was an appropriate and satisfactory approach to workplace interpreting. The responses in both cases were generally very positive, with only one negative outcome being identified. However, this evaluation did not include the interpreters involved in the scheme. We believe that the interpreter possesses much valuable experience that can shed more light on various important aspects of the scheme and its consequences.

The data were comprised of qualitative interviews with 12 interpreters who work in various organizational forms of the scheme. The interviews were video-recorded and later transcribed. Analysis of the data using Grounded Theory produced several themes that were then analyzed in more depth.

One theme emerged, that of "being present in a good way", that seemed to be a common thread binding together several other themes. This theme encapsulated an overarching ideal common to the expressions of all our respondents. It expresses the challenges to that ideal that are inherent in the interpreter's work, especially that of feeling as if one is often in the way or that one is a "foreign body", and of representing one's clients and their message accurately to the other party.

Among the other themes described in the article is an examination of the ECON report's only negative finding; that of the scheme being a crutch for hearing people that lessened their need to use or learn sign language. The question is posed here in terms of whether this is evidence of audism in such environments. Supporting evidence for this view is found in a discussion of language use in the workplace and the question of bilingualism, and of the interpreter's expectations in this regard.

The article also discusses a related topic, that is, how interpreters' relationships with others in the workplace are influenced by the perception of their role. Interpreters' freedom to act, as well as their lack thereof, proves to be an important topic: A variable standard positioned on an ethical spectrum provides a source of conflict for respondents in both types of settings we examine. We argue that a more nuanced ethical practice is called for, and note that such practice decisions must not be made unilaterally by the institutions that regulate the interpreting field, but in cooperation with the user organizations served.

Seeing and being seen encompasses a single phenomenon from two very different perspectives. On the one hand, the interpreter's vantage point makes him or her the only party who can fully "see" both sides, and as such, the one in the best position to see why communication works and why it sometimes falls apart. Interpreters struggle with a feeling of powerlessness when they see things they consider unjust. On the other hand, being seen refers both to the impossible ideal of the interpreter's invisibility and to the concept of the "courtesy stigma" to which the interpreter, by the nature of his or her profession, is subject.

After a discussion of the findings, we conclude with implications for research, education and practice in a quickly evolving interpreting profession. 


\section{Innledning}

Lov om folketrygd §10-7 f lovfester døves rett til nødvendig og hensiktsmessig tolketjenester i livets daglige gjøremål (Folketrygdloven, 2008; Arbeids- og velferdsdirektoratet, 2014). I 1999 ble det gjennomført et prøveprosjekt der døve arbeidstakere som hadde felles arbeidsplass kunne frasi seg individuell rett til tolk på arbeidsplassen (på den tiden opptil 90 timer per kvartal i 100\% stilling) og overføre timene til en fellespott. Beregningsnøkkelen som ble brukt var at tre årsverk kunne utløse én tolkestilling. Målet var å kunne håndtere spontane tolkebehov på arbeidsplassen når de oppsto, noe som neppe ville være mulig hvis man skulle ringe til tolketjenesten og bestille tolk. I tillegg kunne ansatte tolker integreres på arbeidsplassen og bli kjent med bedriftens struktur og kultur, medarbeiderne og ikke minst fagterminologien som brukes. Dette skulle lette kommunikasjonen, siden man da slapp å lære opp tolken hver gang.

Forsøksordningen ble evaluert internt av daværende Helse- og sosialdepartementet og funnet vellykket, og ordningen Tolk på arbeidsplass (TPA) ble gjort varig og landsdekkende i 2001. En evaluering (ECON, 2004) viste at tilbakemeldingene fra både hørende og døve brukere var veldig positive. Derimot ble det ikke innhentet noen tilbakemelding fra tolkene. Rapporten omtaler tolker, men kun som ressurs. Det hevdes at noen tolker tok initiativ til a dele sine observasjoner, men det finnes ikke noen indikasjoner på dette i selve rapporten.

TPA for døve tegnspråkbrukere har nå eksistert i 15 år, men den eneste større evaluering av ordningen (ECON, 2004), er nå blitt ti år gammel.

I tiden etter at ordningen ble gjort varig, er det også blitt åpnet for forskjellige prøveprosjekter som skiller seg organisatorisk og praktisk fra den opprinnelige TPA. Denne artikkelen bygger på min masteroppgave om erfaringene til tolker som arbeider i noen av disse ulike formene for TPA i en av Norges største byer (Evans-Jordan, 2014). I artikkelen vil jeg gjøre rede for de teoretiske og metodiske elementer som underbygger studien, og presentere noen av de viktigste funnene. Det som kommer frem er at tegnspråktolking $\mathrm{i}$ offentlig sektor kjennetegnes av tolker med et sterkt ønske om "å være til stede på en god måte" samtidig som de strever med yrkesutøvelsen i skiftende etiske paradigmer.

\section{Teoretisk forankring}

Det er mange måter å forstå funksjonshemning på. I ytterkantene av spekteret finner vi henholdsvis den medisinske modellen og den sosiale modellen. Tilhengere av den medisinske modellen forstår funksjonshemning som et avvik fra normen, som de patologiserer. Funksjonsnedsettelsen og dens konsekvenser anses som iboende i individet og utgjør dermed et individuelt problem. Forkjemperne for den sosiale modellen skjelner på sin side mellom funksjonsnedsettelse (impairment) og funksjonshemning (disability). De hevder at en funksjonshemning oppstår kun i en gitt kontekst hvor det å ha en bestemt funksjonsnedsettelse medfører ulempe (se for eksempel Shakespeare, 2006; Davis, 2006; Kermit, 2006 og Lane, 2002).

Gjennom sin konstruksjon av begrepet bidrar den medisinske modellen til å opprettholde og påføre stigma. "Uønskede og tvilsomme egenskaper" (Kermit, 2006, s. 48) som Goffman (1963) betegner discreditable, åpner for stigmatisering og marginalisering, i første omgang av individet, men også av familiemedlemmer, venner og profesjonsutøvere som har med den stigmatiserte å gjøre. Når personer i omgangskretsen blir utsatt for stigma, kaller Goffman (1963) det for courtesy stigma, der stigma "smitter" andre. Uansett om de er bevisst denne stigmatiseringen eller ikke, kan tegnspråktolker tidvis oppleve ubehag i møter mellom det hørende storsamfunnet og den døve minoriteten. 
Tegnspråktolker og talespråkstolker kan ha mange sammenlignbare erfaringer, deriblant å være vitne til stigmatisering av sine minoritetsbrukere, og kanskje å oppleve à bli stigmatisert selv. Det som imidlertid skiller tegnspråktolken fra sine talespråktolkekollegaer, er at tegnspråktolkens minoritetsspråklige brukere oftest er døve eller tunghørte. En hørende, fremmedspråklig (talespråklig) tolkebruker har de fysiologiske forutsetninger for å klare seg uten tolk etter en stund. Til forskjell vil en tegnspråktolk potensielt kunne følge sine tegnspråklige døve brukere fra barndommen inn i voksenlivet.

Historisk har døvetolkene, som de het tidligere, vært personer som sto de døve nær, som foreldre eller barn av døve, naboer, eller lærere eller prester for døve. De opererte som hjelpere med et ubevisst konsekvensetisk ståsted (Kermit, 2001), ut fra tanken om at det viktigste var å oppnå et best mulig resultat, det vil si en løsning på det som utløste tolkebehovet. Etter hvert som tolkeaktiviteten begynte å ligne mer på et yrke, ble også fokuset på rollens etikk viktigere: Hva er en tolk, og hva bør (eller ikke bør) tolken gjøre? Og videre, hvem skal ha lov til å bestemme hva som er et godt resultat? Skiftet fra konsekvensetikk til pliktetikk kom som et resultat av profesjonaliseringsprosessen. Nå skulle en tolk kun være et språklig mellomledd, og tolken skulle følge regler som ivaretok partenes rett til selvbestemmelse. Men heller ikke pliktetikken kunne tilby fasitsvar på alle yrkesutøvelsens dilemmaer, selv om den tjente som et viktig regulerende virkemiddel i den tidlige fasen av tolkeyrkets profesjonaliseringsprosess.

Etiske retningslinjer pleier å utvikle seg i takt med profesjonene som de regulerer. Tross dette forekommer det situasjoner hvor reglene ikke synes å være hensiktsmessige, og hvor tolker bevisst agerer utenfor reglene. Wadensjö (1993/2002, 1998), Metzger (1999), og Roy $(1993 / 2002,2000)$ var blant dem som avdekket mytene om tolkens nøytralitet og usynlighet og viste at tolker på ulike måter faktisk var aktive deltakere i tolkemedierte situasjoner. Berge (2003) forteller om skoletolkens handlinger i klasserommet og oppfordrer til en ny utredning av tolkens rolle basert på sosiokulturell teori. Leneham og Napier (2003) hevder at daværende etiske retningslinjer ikke var fleksible nok til å ivareta en tolkerolle i endring. Både Tate og Turner $(1997 / 2002)$ og Kermit (2001, 2004) gjør rede for misforholdet mellom teoretiske, etiske, og praktiske krav til tolken og krever dialog rundt den nye tolkegenerasjonens etikk.

Forskning på amerikansk tegnspråk (ASL) på 1960-tallet (Stokoe, 1960) ble nøkkelen til den lingvistiske forståelsen av tegnspråk som et fullstendig og naturlig språk. Det bidro også til profesjonaliseringen av tolkeyrket (Cokely, 2005). Forskning på tegnspråktolking fulgte samme mønster som for talespråktolking og oversetting; forskere så på tolken som en nøytral kanal som informasjon fløt gjennom (Metzger, 1999). Idealet i både forskning og yrkesutøvelse ble mest mulig ekvivalens av både betydning og form mellom originaltekst og tolket versjon og mest mulig fravær av tegn på tolkens subjektivitet eller innflytelse på budskapet. Idealet om steril nøytralitet og tolkens usynlighet skulle komme til å prege den fremvoksende profesjonen i lang tid fremover. På den ene siden bidro det til å utvikle rammer for en felles profesjonsforståelse, på den andre siden kunne det tidvis føre til rigid utøvelse av profesjonen.

Min studie tar utgangspunkt $i$ at tolken har et unikt perspektiv i og på den tolkemedierte samtalen, og derfor har viktig innsikt. Som Nilsen (2011, s. 66) også trekker frem i en diskusjon om talespråktolking i offentlig sektor i Norge, er det ofte «bare tolken [som] har mulighet for å få vite hva som egentlig blir sagt.» Dette gir tolken stor makt og stort ansvar. Samtidig er tegnspråktolker, takket være en treårig bachelorutdanning i tegnspråk og tolking, gjerne i stand til à reflektere over kommunikasjon, tolketeknikk, tolkerolle og etiske perspektiver, og til å bruke denne refleksjon til å forbedre tjenesten de yter. 
I denne artikkelen defineres samtlige som benytter seg av tolkens tjenester, både døve og hørende, som "tolkebrukere". Selv om det per i dag er den døves hørselsstatus som utløser rettigheter til tolk, understreker tegnspråktolker i studien en bevissthet om at de er den hørendes tolk like mye som den døves. Denne språkbruken reflekterer en sosial holdning til døvhet, siden den gir uttrykk for at begge parter trenger bistand for å kommunisere med hverandre.

\section{Metode og datamateriale}

Etter at mitt mastergradsprosjekt ble godkjent av NSD ble informanter rekruttert ved at informasjonsskriv og rekrutteringsbrev ble sendt til tre institusjoner som tilbyr tjenesten tolk på arbeidsplass. Vedlagt hvert rekrutteringsbrev var et skjema for informert samtykke og kontaktinformasjon. Enhetsledere ble bedt om å dele ut brev til tolker som oppfylte inklusjonskriteriene (fylt 18 år, minst ett år i jobb som tolk og minst seks måneder i TPA). Av 15 mulige respondenter sendte 12 tolker inn samtykkeformular, noe som utgjør en svarprosent på 80 . Jeg valgte å intervjue alle som meldte sin interesse; sammensetningen av respondenter var gunstig da de representerte ulike former for TPA, og såpass mange respondenter ville gi mulighet for bedre belysning av problemstillingen.

Utvalget består av ti kvinner og to menn, noe som gjenspeiler kjønnsfordelingen blant tolker i populasjonen (L. Røsvik, personlig kommunikasjon, 25 april 2014). På intervjutidspunktet var de mellom 28 og 50 år. Respondentene jobber på tre forskjellige arbeidsplasser som tilbyr en eller annen form for TPA.

Den første gruppen er tolker i den fylkeskommunale tolketjenesten. Tolkene i denne TPAgruppen reiser til og fra en rekke ulike arbeidsplasser, deriblant attføringsbedrifter og arbeidskvalifiseringstjenester rettet mot døve innvandrere. De tolker ofte på møter, i lunsjog kaffepauser, og på medarbeidersamtaler. Halvparten av respondentene tilhører denne gruppen.

Den andre halvparten av respondentene arbeider på to arbeidsplasser som kjennetegnes av en høyere andel døve medarbeidere og hvor tolkene er "hustolker" som "går i miljøet". Tolkene er til stede på arbeidsplassen også når de ikke tolker.

Informantene har i gjennomsnitt 8,5 års tolkeerfaring og 3,25 års erfaring i TPA. De utgjør en blanding av erfarne og nyutdannede tolker. Noen har forbindelser til døvemiljøet som har påvirket deres valg, mens andre kom tilfeldigvis til yrket. Dermed er de fleste av både tolkeyrkets og tolkeutdanningens utviklingsstadier representert (Erlenkamp et al., 2011; Woll, 1999).

Intervjuene ble gjennomført ved hjelp av en semistrukturert intervjuguide. Guiden ble finjustert etter hvert under datainnsamlingsprosessen. Den ga nok struktur til at ingen viktige temaer ble glemt, og nok fleksibilitet til at tolkene kunne snakke fritt rundt problemstillinger som de var opptatt av. Alle deltakerne samtykket i videoopptak av intervjuet. Opptakene ble så transkribert til ren tekst og avidentifisert.

Jeg har med vilje tegnet et litt uklart bilde av respondentene i denne studien. Dette gjør jeg for å ivareta anonymiteten til en liten gruppe tolker som igjen tjener en liten og sårbar gruppe tolkebrukere. I noen sjeldne tilfeller har jeg utydeliggjort detaljer i fortellinger som jeg mente kunne for lett identifisere individer. 
I arbeidet med å analysere datamaterialet brukte jeg sosialkonstruktivistisk grounded theory (Charmaz, 2005, 2006, som sitert i Creswell, 2007). Dataene ble kodet etter hvert som temaer kom til syne. Temaene ble analysert og kategorisert i henhold til mønstrene som jeg oppdaget blant de kodete dataene. I den neste delen av artikkelen vil jeg gi en tematisk presentasjon av noen av studiens funn som har relevans for tolking $\mathrm{i}$ det offentlige.

\section{Funn og diskusjon}

Det å være til stede på en god måte ... det er at det skal være greit at jeg er der.

En erfaren tolk sa disse ordene flere ganger $\mathrm{i}$ et intervju tidlig i studien. Hun ga uttrykk for en bevissthet om at tolkens virksomhet ikke er uproblematisk, at en tredje person nødvendigvis endrer dynamikken, at tolken av og til rett og slett står i veien. Men utsagnet kan også tolkes som et slags overordnet mål. Utsagnets flertydighet reflekterer mangfoldet i tolkenes yrkesutøvelse og de mange ulike utfordringene som de står overfor i fors øket på "å være til stede på en god måte". I denne delen vil jeg presentere og diskutere noen av studiens funn. På mange måter dreier de alle seg om tolkens tilstedeværelse i tolkesituasjonen, både om hva som gjør at dette oppleves som vellykket, at det er greit at tolken er der, men også om hva som er utfordrende ved å være der.

\section{TPA-soveputen: audisme videreført?}

ECON-rapporten (2004) kritiserte kun ett aspekt ved den praktiske utføringen av TPA:

Brukerne har svært lite negativt å si om ordningen. Et moment som trekkes frem er imidlertid at ordningen kan bli en "sovepute" for de hørende. Lett tilgang til tolk bidrar til at hørende kollegaer, som kan noe tegnspråk, baserer seg på tolkehjelp istedenfor for å bruke det de kan. Hørende, som ikke behersker tegnspråk, kan på grunn av ordningen velge bort egen opplæring i tegnspråk. (s. 29)

Denne innvendingen, fremført for ti år siden av tolkebrukere i bedrifter med en høy andel døve medarbeidere, bekreftes i denne studien av tolker som jobber i samme type bedrifter $\mathrm{i}$ dag. I bedrifter som tilbyr tjenester til døve, og som i noen tilfeller også har tegnspråkkompetanse for alle ansatte som et uttrykt mål, kan TPA ha en utilsiktet og uheldig konsekvens. Tolkens stadige tilstedeværelse kan motvirke utviklingen av allmenn tegnspråkkompetanse og hindre likeverdig kommunikasjon og arbeidsvilkår for personalet.

Begrepet audisme, introdusert av Tom Humphries i sin doktorgradsavhandling (Humphries, 1977), beskriver forestillingen om at man er overlegen på grunn av evnen til å høre eller til å opptre som en hørende. Audisme betegner diskriminering på grunn av (manglende) hørsel (se Harrington \& Jacobi, 2009). Når TPA blir en sovepute for hørende i bedrifter hvor forventningen om tegnspråklig kommunikasjon finnes, kan tolkeordningen i disse tilfeller fungere mot sin hensikt, virke undertrykkende og videreføre audisme. Studien viser at sånne forhold er årsak til mye frustrasjon blant både tolker og døve tolkebrukere. Siden det er nettopp forventninger om tospraklighet som ligger til grunn for spørsmålet om audisme, skal vi gå nærmere inn på begge deler. 


\section{Tospråklige arbeidsplasser?}

Selv om begrepet 'tospråklig arbeidsplass' brukes hyppig av tolker og andre i tegnspråkmiljøet i Norge, er det ikke gitt hva som legges i det. Blant språkvitere er det like komplisert à definere tospråklighet som det er å si hva som menes med "flytende" språkferdigheter. I vår kontekst handler tospråklige arbeidsplasser egentlig om hørende medarbeideres tospråklighet og arbeidsplassens tegnspråklighet. Stadshaug og Foote (2010) presenterer imidlertid en annen definisjon der tospråklige arbeidsplasser er arbeidsplasser hvor individer med forskjellige språk jobber sammen. Med en slik definisjon er det vanskelig å forestille seg en arbeidsplass som ikke er tospråklig. Man kunne kanskje rettere snakket om tegnspråklige arbeidsplasser der det er mange arbeidstakere som kan tegnspråk, og tolkeavhengige arbeidsplasser der det er en tegnspråkbruker blant mange ikke-tegnspråkkyndige.

Det virker kanskje ikke naturlig å tenke på en arbeidsplass som tospråklig med bare én tegnspråklig ansatt blant et hundretall talespråklige, som Stadshaug og Foote vil ha oss til å gjøre. Likevel mener jeg at begrepet kan forsvares fra et sosiokulturelt perspektiv. Dersom den første merkelappen en person får på en ny arbeidsplass er lingvistisk istedenfor medisinsk, eller dersom den hørendes første møte med døve kan innrammes på en sosiokulturell istedenfor en medisinsk måte, kan det bidra til anerkjennelse av den døve for alt han er og har, istedenfor for det han mangler (se også Bauman \& Murray, 2009). Da bidrar man sakte, men sikkert til å bryte ned fordommer og barrierer, og åpner veien for et mer åpent, forståelsesfullt og inkluderende samfunn.

Det nærmeste vi kommer "ekte" tospråklige, det vil si tegnspråklige, arbeidsplasser i vår studie, er et regionalt kompetansesenter og et helse- og velferdstilbud rettet mot døve hvor også flere døve jobber. Selv i disse organisasjonene finner man stor variasjon i språkferdighetene blant de hørende medarbeiderne. Imidlertid har ikke alle de ansatte stillinger som innebærer daglig kontakt med døve ansatte, og tospråkligheten blir dermed utviklet og praktisert i varierende grad.

\section{Forventninger har alt å si}

Halvparten av tolkene i vår studie jobber for en fylkeskommunal tolketjeneste i NAV. De reiser rundt til flere arbeidsplasser om dagen og tolker mye på attføringsbedrifter i forbindelse med arbeidsavklaring og på tiltak rettet mot minoritetsspråklige døve innvandrere, men også på andre arbeidsplasser. Her har de færreste hørende tolkebrukere noen erfaring med døve, med unntak av noen få ledere ved attføringsbedriftene som har jobbet med døve før. I disse situasjonene hvorav de fleste er tidsbegrensede, individrettede tiltak, ville en forventning om tospråklighet norsk/norsk tegnspråk selvsagt ha vært urimelig. Tolker på disse arbeidsplassene forventer ikke tegnspråkferdigheter blant hørende tolkebrukere. Derfor applauderer de hver eneste gest som tas i bruk, og de svarer gjerne på spørsmål om hvordan kommunisere med døve. De opplever ikke uvitenhet som tegn på negative holdninger blant hørende, men lærer i stedet gjerne bort "tips og tricks" og "hjelp til selvhjelp".

Den andre halvparten av studiens deltakere er tolker som jobber daglig sammen med mange døve og med hørende som vanligvis kan (i det minste litt) tegnspråk. Noen av disse jobber i organisasjoner hvor det foreligger et uttrykt mål om tospråklighet blant alle ansatte. Med sterke bedriftspolitiske føringer og forventninger og en relativt høy andel tospråklige/tegnspråklige medarbeidere, er det lett à se at også tolkene utvikler høye 
forventninger til de språklige og kommunikative forholdene på arbeidsplassen. Det er her at misforholdet mellom forventninger og realiteten oppstår. Respondentene beretter om flere forhold som er årsak til misnøye blant både tolker og døve. En tolk peker på et viktig forhold på arbeidsplassen når hun sier: "Men det kan ligge mer en sånn - en utfordring i det der med språkmiljøet, at ... fordi de døve også her er en minoritet ... De er færre enn majoriteten, som er hørende." Til tross for at tegnspråk "er en del av det store arbeidsmiljøet her", kan uinnfridde forventninger til språkkulturen splitte arbeidsplassen:

Det er jo nesten sånn at når man sitter på et lunsjbord, så er det liksom vi døve og de hørende. Og da er jo vi tolker og andre som kan tegnspråk godt ikke med i den hørendegruppa, sånn at det egentlig er et språkskille der også. Og da ligger jo utfordringen $\mathrm{i}$ at en del prioriterer det så lavt å lære seg nok tegnspråk - eller prioriterer det så lavt å bare få disse her hendene opp ... så blir vi litt bundet til å gå i visse miljøer når det er pauser her, tenker jeg.

Tolkens eget behov for sosial kontakt i pausene blir underordnet de kulturelle reglene hun føler seg til en viss grad alene om å følge; hun kan godt tenke seg forskjellige samtalepartnere, "men hvis jeg da setter meg på et annet bord [der det snakkes talespråk], så kommer det jo noen døve dit, og da må jeg automatisk tolke der." Hun er overbevist om at dersom hun lot være å tolke, "er det jo ingen sånn bevissthet hos de andre som også sitter på lunsj da om at 'nå må jeg jo løfte hendene [snakke tegnspråk], for her er det jo noen som ikke hører hva jeg sier'." I dette eksempelet blir tolkens tilstedeværelse en sovepute for de andre. De trenger ikke snakke tegnspråk når en døv setter seg ved bordet fordi det er en tolk der.

Kulturelle regler som det å bruke tegnspråk når en døv person er til stede, eller å plassere seg sånn at alle $\mathrm{i}$ en gruppe kan se når man skal kommentere noe i plenum, er viktige. $\AA$ følge sosiale normer er et tegn på at man opplever å være en del av et fellesskap, mens man kan definere seg som utenfor gruppen ved å ignorere normene.

Tolkene har lett for å unnskylde ansatte som ikke har med døve å gjøre til daglig, men retter hard kritikk mot andre som jobber med døve til daglig og som de mener burde vite bedre, og særlig hvis de mener oppførselen deres signaliserer audisme på arbeidsplassen.

En tolk forteller om en type møte som synes å gå igjen på arbeidsplassen. Til stede på møtet er flere hørende og to døve som alle bruker tegnspråk med hverandre sosialt. Selv med god tegnspråkkompetanse hos alle deltakerne, og derfor gode forutsetninger for ikke å bruke tolk, foregår møtet på talt norsk og blir tolket til tegnspråk. "Og det medfører jo at det selvfølgelig er turtaking på talespråkets premisser." Dette fører til at døve ikke får delta på møter på lik linje med hørende kolleger (Herreweghe, 2002). Tolken gir uttrykk for sin frustrasjon:

Det handler om at man kunne ha sagt dette her direkte, hadde man hatt litt ønske om at alle skulle bli gode i tegnspråk, eller hadde man hatt et sånt språkønske om at 'jeg jobber med døve, så jeg vil selvfølgelig være god i tegnspråk, og jeg har som ambisjon å også bli god i døves språk', så ville dette ha løst seg helt automatisk, hvis det hadde ligget en sånn forventning i miljøet.

Tolkens primære oppgave er å muliggjøre kommunikasjon mellom to parter som ikke deler et felles (arbeids-)språk. Her blir tolketjenester benyttet ikke for å muliggjøre kommunikasjon, men for å muliggjøre at arbeidet utføres på hørendes premisser. Langvarige eller gjentatte konflikter mellom døve og hørende om hvilken språkkode som skal dominere, er blitt til "et snev av misnøye" og "en stemning som ikke er helt god". 
Eksempelet ovenfor handler om en gruppe som ifølge informanten har de nødvendige språklige forutsetningene for å ta møtet direkte, uten tolk. Når de språklige forutsetningene derimot ikke er til stede kan døve synes det er strevsomt med hørende som har dårlig tegnspråk. Dette kommer også frem i datamaterialet der en gruppe med varierende tegnspråkferdigheter gjør gjentatte forsøk på å bli enig om språkform på møter: "Men så kan de døve da komme inn og si at 'ja, men ... jeg forstår ikke helt hva du sier'". Men når språkvalgets begrunnelse lyder "Alle kan jo tegnspråk, men at nei, det vil vi ikke bruke, for da er det så vanskelig å skrive referat", da er det grunn til å si at språkvalget og bruk av tolk tilrettelegger for at arbeidet utføres på hørendes premisser.

Bedrifter med en høy andel døve ansatte er pliktetikkens siste skanse. I motsetning til NAV, hvor partenes manglende erfaring tilsier og i noen tilfeller nødvendiggjør et større handlingsrom for tolken, og hvor tolken kan være med på å angi tonen i et arbeidsforhold, er tonen her for lengst satt. Partenes, deriblant også tolkenes, forventninger til tolkens nøytralitet setter stopper for en alliert tilnærming til dialog og forhandling om språkkulturen på arbeidsplassen.

\section{Identitetskrise?}

I både ECON-rapporten og i denne studien gir partene uttrykk for at tolkene har en klar forståelse av når de er kolleger og når de er tolker:

Problemer knyttet til det at bruker og tolk er kollegaer er i liten grad diskutert blant de ansatte. Det oppfattes ikke som et problem. Det gjennomgående inntrykket er at tolkene er svært profesjonell og bevisste på dette; de er først og fremst tolker, så kollegaer. Ved medarbeidersamtaler og andre sensitive samtaler har brukerne ved våre casevirksomheter mulighet til å benytte ekstern tolk. (2004, s. 28)

Dette betyr ikke at rollesammensetningen er uproblematisk (Dickinson \& Turner, 2008); det at det ikke problematiseres kan heller tyde på at temaer som blant annet døves likestilling på arbeidsplassen (Harris \& Bamford, 2001) og tolkens posisjon som alliert (Baker-Shenk, 1991) ikke tas opp.

\section{Proffe tolker og proffe brukere}

I minst én av de relevante organisasjonene forteller tolkene at døve medarbeidere, selv om de har rett til ekstern tolk, gjerne benytter seg av egne tolkekolleger, også når det gjelder sensitive samtaler. En tolk begrunner dette med at erfaringsgrunnlaget med tolk som profesjonell yrkesutøver er bygget opp over tid. "De vil bruke oss ... Det tror jeg handler om at vi er proffe tolker og de er proffe brukere. Jeg sier også at de er proffe brukere." Pliktetikkens kjente og trygge rammer tjener partene bra når det gjelder saker hvor den eneste bistand som tolkebrukerne trenger, er tolkefaglig. Alle parter blir trygge på at tolken er bare tolk, og de husker ikke engang hvem av husets tolker som var med på de ulike samtalene. 


\section{Kolleger?}

Spørsmål om grensen mellom kollega og tolk dukker ikke opp for NAV-tolkene. For dem er det mer relevant å snakke om samarbeidspartnere og tolk/medmenneske. En respondent forteller at selv om man med tiden kan både le og gråte sammen, er det fortsatt en annerledeshet som gjør at de ikke hører helt til. Hun oppsummerer det slik:

Jeg tror nok at det kan være en del at man også føler seg ... på plass da. Jeg tror det er viktig når vi tolker på de samme stedene kanskje i mange, mange år - vi er ikke en ansatt der, vi er ikke en kollega, men vi er her likevel, nesten hver dag. Hva er vi? $\mathrm{Vi}$ begynner å kjenne de andre rundt bordet. Vi kan hva kona di heter, hva barnebarnet ditt heter, hvor du er født og oppvokst, hva gjorde du i helga. Vi vet alt det der.

Likevel blir ikke alt av delte opplevelser og intim kunnskap nok til at tittelen kollega blir brukt. Den samme respondenten svarer på eget spørsmål; "Hva er vi?" slik:

Vi møtes som en slags kollegaer. Eller vår møteform er den samme som med en kollega. Og din kollega er den døve personen ... Og dere to har en relasjon uten meg. Men jeg er her som en del av din relasjon til den døve kollegaen din.

Denne respondenten var den desidert mest liberale med kollega-definisjonen, men det viste seg å være en "veldig sterk kollegial tilhørighet" med andre tolker som gjorde at sistnevnte ble betegnet som kolleger. En annen respondent begynte med å si at folk ved bedrifter hun hadde vært på i mange år var "nesten sånne mine kolleger til låns," men korrigerte seg straks, "mer samarbeidspartnere, egentlig."

Når ens yrkesutøvelse har karakter av å være så ambulerende og skiftende, er det vel naturlig at det er andre tolker, og i økende grad også andre ansatte på hjelpemiddelsentralen som tolkene tenker på som kolleger.

Det som kan sies er at NAV-tolker gir uttrykk for sterk tilhørighet til NAV. Noen praktiske og rollemessige utfordringer løses ved hjelp av ansettelsesforhold. Dette diskuteres i neste avsnitt.

\section{Tolkens handlingsrom}

Tolkens handlingsrom må forstås med bakgrunn i den tautrekkingen mellom konsekvensog pliktetikken som har pågått siden tolkeyrkets spede begynnelse.

Samordningsarbeidet (Wadensjö, 1998) som NAV-tolkene påtar seg trekker hardt i tauet på konsekvensetikkens side. Mens tolkene på arbeidsplasser med en høy andel døve beskriver sine brukere som "proffe brukere", jobber NAV-tolkene mye med uerfarne tolkebrukere, både hørende og døve. En erfaren tolk bemerker at andre tjenestemottakere på hjelpemiddelsentralen får rikelig med opplæring i bruk av hjelpemidler som rullestol, mens døve på sin side ikke får et eneste kurs i hvordan bruke tolk:

Og en tolk er en levende person. Det er veldig komplisert, egentlig (ler litt). Så det er noen brukere som burde hatt kurs - for en tolkesituasjon er et felles prosjekt. Man må samarbeide. Og mange vet ikke hvordan man skal samarbeide. 


\section{Opplysningsplikt: å tøye grenser?}

Samtidig som de innrømmer at det er en tøyning av grensene, påberoper NAV-tolkene seg veiledningsplikten de har som statsansatte. Forvaltningsloven $\S 11$ gir dem ikke bare lov, hevder de, men "nesten litt plikt" til å agere utover det som tolkerollen strengt tatt tilsier. Den samme tolken forteller:

Hvis man helt klart fornemmer og føler at ... de vet ikke hvordan de skal gå videre... Og vi som tolker, vi kjenner de store aktørene som er i NAV-systemet, som hjelper døve ut i arbeidslivet. Ja, for å hekte på - for å få ting til å gå videre, hvis ikke så blir jo den døve igjen - man må ha et nytt møte og et nytt møte og et nytt møte ... Så kan vi bare gi en opplysning om at det [er løsningen]. Så slipper man tre møter til. Det er jo nesten en del av forvalteransvaret som vi også har som tolker.

At det kan ha vært riktig å gi tips i et sånt tilfelle, er et syn det er lett å forsvare. Det som er viktig å reflektere over, er hva slags forvalteransvar en tolk bør føle seg pålagt. Tolken agerer "i tråd med NAV sitt mål om inkluderende arbeidsliv" og er klar over at det "ikke [er] tolkeplikt, men NAV-ansattplikt" som motiverer valget. Tegnspråktolkeyrket styres av et etisk ideal om upartiskhet som ofte blir tolket som flerpartiskhet; at tolken skal engasjere seg like mye for alle parter. Spørsmålet her dreier seg om hvorvidt denne opplevelsen av veiledningsplikt og forvalteransvar på tolkens side i virkelighet befinner seg utenfor tolkerollen og grenser til NAV-partiskhet, og hva dette kan innebære for tolkens maktrelasjon, særlig til den døve parten.

I NAV-rapporten Fornying av tolketjenesten (Hjort, 2011) blir det gjort rede for en utvidelse av tolkerollen, og særlig verdt å legge merke til, er en anbefaling om kompetansebygging innenfor et område de kaller "funksjonsvurdering". Rapporten ble møtt med sterk skepsis i et innlegg publisert i både Døves Tidsskrift og Tolkeavisa (Skaten, 2012). Her stiller man seg undrende til forslaget og bemerker at i arbeidsgruppen som utredet forslagene var det ingen representant fra brukerorganisasjonene med. Det er særlig underlig i en tid med økt fokus på brukermedvirkning. Forslaget, og særlig det at det var utarbeidet uten brukermedvirkning, kan virke mot sin hensikt ved å undergrave tilliten til tolkeyrket, som på mange måter fortsatt er under utvikling og oppbygging. Faren består i å ta enda mer makt fra en gruppe som fra før har lite makt og er klart underrepresentert i utredningsarbeidet. Forslaget om utvidelse av tolkerollen og påleggelse av forvalteransvar, uten samtidig å gjennomføre en mer transparent, inkluderende og grundig etisk vurdering, er svært vanskelig å begrunne eller forsvare. 


\section{Bundne hender}

Hustolkene i studien styrer tolkesituasjoner i mye mindre grad enn sine kolleger i NAV. Ofte skyldes dette at de erfarne tolkebrukerne selv tar styringen. Noen ganger derimot, følte tolkene seg som de var bundet på hender og føtter. Særlig i situasjoner som de opplever som undertrykkende, føler de seg maktesløse. Tross mye frustrasjon er terskelen for intervensjon i denne tolkepopulasjonen veldig høy. Langvarig og institusjonalisert underlegenhet førte til avmaktsfølelse selv blant ressurssterke døve. En tolk forteller:

Så har jeg tenkt litt på at hva er mitt ansvar som tolk? Hva slags ansvar kan jeg legge på de døve? Hva slags ansvar kan jeg legge på møteleder? Og det som av og til hender da, det er jo at døve kommer til oss og sier at å, nå er jeg så frustrert fordi de hørende ikke gidder å reise seg [plassere seg sånn at alle i gruppen kan se] ... Og det at de kommer til meg som tolk, det - På én måte så er det litt ubehagelig, fordi at da vet jeg at OK, nå er du frustrert. Men samtidig så er det - hvorfor sier du det til meg? Hvorfor kan du ikke si det til lederen din? Da har det blitt sånn at jeg har sagt ifra til den døve som kommer til meg, at dette her må du ta videre, dette her er ikke noe som jeg kan gjøre noe med.

Her er tolken kommet i en situasjon hvor forventninger til tolkens oppførsel har stengt for

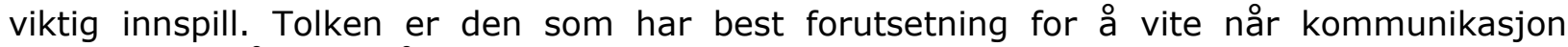
fungerer og når den går i stykker. Partene kan føle misnøye med en tolket samhandling, men det er tolken som vet hvorfor det er sånn. Dersom døve, som leseren vil huske er $\mathrm{i}$ minoriteten selv $\mathrm{i}$ tegnspråklige arbeidsmiljøer, føler at de ikke når frem med ønsker om bedriftskulturelle endringer, da må man vurdere om pliktetikken er det som tjener arbeidsforholdet best. Ledelsen kan med fordel åpne for å formalisere partenes og tolkenes innspill. Dermed kan det bli mulig å ta tak i forhold som går ut over medarbeidernes og tolkens jobbtrivsel og som ellers ville ha forblitt et irritasjonsmoment.

\section{$\AA$ se og å bli sett}

Tolkene står i kommunikasjonens førstelinje hver dag. Som eneste part både utdannet til det og med full fysiologisk tilgang til hele episoden, har de en unik mulighet til $a$ se forskjellige aspekter ved samtalen på en hermeneutisk fortolkende måte. Hver erfaring kan bidra til kunnskapsbygging for den reflekterte tolken.

Samtidig kan måten andre ser på tolken og den døve i tolkesituasjonen, påvirke hvordan tolkene opplever både seg selv som tolk, tolkebrukere og tolkeyrket i det hele tatt. De opplever å bli sett på som en forlengelse av den døve parten; flere respondenter gir uttrykk for ubehag i situasjoner som setter døve og/eller tolk i dårlig lys:

Man skal ha sterk rygg som tolk hvis man skal stemmetolke sånn som det nesten faktisk blir sagt. [...] Vi er litt redd for å tape litt ansikt sjøl, fordi det er vi som må lage de norske setningene da. For arbeidslederen kan kanskje snu seg og se litt rart på oss, tolken, hvis vi sier litt det samme som - ikke sant.

En annen sier: "Jeg klarer ikke å snakke gebrokkent," og forklarer at hun må finne andre måter for å "gi et riktig bilde" av den døve personen. Dette gjør hun blant annet ved å rette den hørende partens oppmerksomhet mot visuelle signaler som skal avsløre dette "riktige bildet". Hun peker ut disse signaler og sier: "Ser du...?" Denne typen ubehag tyder på at tolker opplever den smittsomme courtesy stigma som Goffman (1963) beskriver. 


\section{Tolken som fremmedelement og Den nye usynligheten}

Særlig i forbindelse med nye arbeidsplasser og/eller uerfarne tolkebrukere, opplever NAVtolker at de selv kan stoppe for naturlig kommunikasjon ved lunsjbordet. En av studiens mest erfarne tolker forteller om denne fremmedelement-effekten:

Jeg har en rolle som også går ut på å gjøre meg tilgjengelig som tolk, sånn at ikke jeg blir et fremmedelement som kommer inn og stopper den sosiale kommunikasjonen. Så jeg tenker at en skal heller være kommunikasjonsfremmende. Men man skal ikke være styrende heller, sånn at man går inn og lager en kommunikasjon som ikke er der hvis ikke jeg hadde vært der. Men det er jo et fremmed menneske som kommer inn.

En annen tilføyer:

For hvis man prøver, som vi sier, å gå i ett med tapetet og bare være veldig nøytral 'nei, jeg er bare tolken, ingen skal legge merke til meg, jeg bare sitter der og tolker. Og hvis noen spør meg: Ja, hvor er du fra? Så bare gir jeg dem et lite sånn ha deg vekk-blikk, og så tolker videre. Eller sier: Nei, det kan jeg ikke svare på, for jeg er bare tolk. Eller: Vil du ha kaffe? Nei, jeg er tolk, jeg'. Da skaper man en mye større avstand enn hvis man sier ja takk til den kaffekoppen, og så står den bare der. Men du har i hvert fall vært litt imøtekommende. Folk spør om du vil ha kaffe kanskje også fordi de er litt usikker - hvem er du? Hva gjør du her?

NAV-tolkene har funnet frem til at den beste måten å dempe oppmerksomheten rundt egen person er å følge de sosiale reglene som signaliserer naturlig tilhørighet til den aktuelle gruppen. De kan for eksempel kommentere været når de merker at rommet blir stille når de kommer inn. De takker ja til kaffekoppen. De bruker spørsmål rettet mot dem fra hørende brukere til å koble den døve brukeren på en samtale. Akkurat som en bemerkning om været synes de det er "unaturlig om vi aldri kunne le når han [der] slår en spøk. Eller at vi ikke kan si: Du, går det bra med deg? Hvis du vet at noen har mistet ektefellen sin." De forteller at den beste måten å bli mindre synlig på, faktisk er å bli synlig på en mer naturlig måte, det vil si å ta i bruk litt mer konsekvensetikk og agere aktivt på gjennomtenkte måter.

Usynlighet og nøytralitet har lenge vært viktige mål i tolkeyrket (Metzger, 1999). Tolkens tilstedeværelse skulle nesten ikke merkes, på samme måte som en oversetter ikke skulle sette sitt eget preg på en annens tekst. Samtidig har blant andre både Metzger (1999), Roy (1993/2002, 2000), og Berge (2003), påvist at tolken, langt fra å være usynlig, er en aktiv deltaker i den tolkemedierte samtalen. Den nye usynligheten er begrunnet deltakelse som motvirker den fremmedelement-effekten. 


\section{Konklusjon}

Studiens deltakere gir uttrykk for at TPA, i alle varianter, hjelper dem å gjøre en langt bedre jobb enn de kunne gjøre tidligere da tolkene nærmest tilfeldig ble sendt ut på ulike oppdrag. Økt tilstedeværelse på en arbeidsplass gjør dem mer "flytende" på det aktuelle arbeidsspråket og de blir bedre kjent med aktørene, fagterminologien og bedriftsstrukturen. Det blir mulig à fange opp spontane tolkebehov. Samtidig kan de oppleve etiske utfordringer som bunner $\mathrm{i}$ et misforhold mellom et opplevd behov for å agere på bestemte måter og de gjeldende etiske retningslinjene.

Det kan være et problem at tradisjonelle holdninger til døvhet får innflytelse på både bedriftskulturelle og politiske beslutninger. Disse holdningene kan true døves likeverdig deltakelse i arbeidslivet. Her kan tolkeutdanninger bidra til et kulturskifte ved å sette fokus på teoretiske modeller om funksjonshemning som gir motvekt til den rådende medisinske modellen. På den måten kan det skapes rom for ærlig og åpen diskusjon rundt holdninger til og stigmatisering av døve.

For at brukerne av tolketjenesten skal ha størst mulig utbytte av tjenesten, er det viktig at brukerorganisasjoner og tolkeorganisasjoner samarbeider om etiske prinsipper som både ivaretar brukernes rettigheter og legger opp til en mer nyansert etisk tilnærming til tolkenes yrkesutøvelse.

Forskningsmiljøet må bidra med relevante studier som kan nedfelle seg i praksis og sikre at profesjonsutøvelsen er kunnskapsbasert. Særlig av interesse etter denne studien er de døve brukernes vurdering av audisme på arbeidsplassen og tolkeetiske beslutninger på systemnivå. 


\section{Referanser}

Arbeids- og velferdsdirektoratet (2014). Tolkehjelp for hørselshemmede [kommentar til forskrift til LOV-2008-12-19-106 § 10-7 Bokstav f]. Utgitt av Arbeids- og velferdsdirektoratet, Tjenesteavdelingen, Tiltaksseksjonen 23.04.2014. Tilgjengelig på www.nav.no/rettskildene/Rundskriv

Baker-Shenk, C. (1991). "The interpreter: Machine, advocate, or ally?" I Expanding Horizons: Proceedings of the 1991 RID Convention, 120-140. Silver Spring, MD, USA: RID Publications. Tilgjengelig på http://library.sccsc.edu/classic/reserves/Interpreter_machine_advocate_or_ally1.pdf

Bauman, H. D., \& Murray, J. (2009). Reframing: From hearing loss to deaf gain. Deaf Studies Digital Journal, 1(1). Tilgjengelig på http://dsdj.gallaudet.edu/assets/section/section2/entry19/DSDJ entry19.pdf

Berge, S. S. (2003). Tegnspråktolkens handlinger. I R. Karlsdottir (Red.) Skriftserien Klasseromsforskning (Vol. nr. 14). Trondheim, Norge: Tapir akademisk forlag.

Charmaz, K. (2005). Grounded theory in the 21st century: Applications for advancing social justice studies. I N. K. Denzin \& Y. S. Lincoln, The Sage handbook of qualitative research (3rd ed., s. 507-536). Thousand Oaks, CA: Sage.

Charmaz, K. (2006). Constructing Grounded Theory. London, England: Sage.

Cokely, D. (2005). Shifting Positionality: A Critical Examination of the Turning Point in the Relationship of Interpreters and the Deaf Community. I M. Marschark, R. Peterson \& E.A. Winston (Red.), Sign Language Interpreting and Interpreter Education: Directions for Research and Practice. New York, NY: Oxford University Press.

Creswell, J. W. (2007). Qualitative Inquiry and Research Design: Choosing among five approaches (2nd ed.). Thousand Oaks, CA: Sage.

Davis, L. J. (2006). Constructing Normalcy: the Bell Curve, the Novel, and the Invention of the Disabled Body in the Nineteenth Century. I L. J. Davis (Red.), The Disability Studies Reader (s. 3-16). New York, NY: Routledge.

Dickinson, J., \& Turner, G. H. (2008). Sign Language interpreters and role conflict in the workplace. BENJAMINS TRANSLATION LIBRARY, 76, 231.

http://dx.doi.org/10.1075/btl.76.12dic

ECON Analyse (2004). Evaluering av "Tolk på arbeidsplass" -en ordning for hørselshemmede arbeidstakere. (Econ-rapport nr. 2004-107). Oslo, Norge: Pöyry Management Consulting.

Erlenkamp, S., Amundsen, G., Berge, S. S., Grande, T., Mjøen, O. M., \& Raanes, E. (2011). Becoming the Ears, Eyes, Voice and Hands of Someone Else : Educating Generalist Interpreters in a Three-year Programme. I L. Leeson, S. Wurm \& M. Vermeerbergen (Red.), Signed Language Interpreting : Preparation, Practice and Performance. Manchester, UK: St. Jerome.

Evans-Jordan, S. (2014). Being present in a good way: Interpreters' reflections on working in staff- and workplace interpreting in Norway. (Masteroppgave,. Norges teknisknaturvitenskapelig universitet (NTNU)). Tilgjengelig på

http://ntnu.diva-portal.org/smash/record.jsf?pid=diva2: 745262

Folketrygdloven (2008). Lov om folketrygd LOV-2008-12-19-106. §10. Tilgjengelig på http://www.lovdata.no/all/tl-19970228-019-034.html

Forvaltningsloven (2014). Lov om behandlingsmåten i forvaltningssaker LOV-2014-05-0916. § 11. Tilgjengelig på http://lovdata.no/dokument/NL/lov/1967-02-10 
Goffman, E. (1963). Stigma-Notes on the management of spoiled identity. London, England: Penguin books.

Harrington, T., \& Jacobi, L. (2009). What is audism? Tilgjengelig på http://libguides.gallaudet.edu/content.php?pid=114455\&sid=989379

Harris, J., \& Bamford, C. (2001). "The Uphill Struggle: Services for Deaf and hard of hearing people - issues of equality, participation and access." I Disability and Society, 16(7), 969-979. http://dx.doi.org/10.1080/09687590120097854

Herreweghe, Mieke van (2002). Turn-Taking Mechanisms and Active Participation in Meetings with Deaf and Hearing Participants in Flanders. I C. Lucas (Red.), TurnTaking, Fingerspelling, and Contact in Signed Languages. (Vol. 8, s. 73-103). Washington, D.C.: Gallaudet University Press.

Hjort, P. (2011). Fornying av tolketjenesten. (Arkivref. 10/2126). Oslo, Norge: NAV $\mathrm{Hjelpemiddler} \mathrm{og} \mathrm{tilrettelegging.}$

Humphries, T. (1977). Communicating across cultures (deaf-hearing) and language learning. (Doctoral dissertation.) Cincinnati, $\mathrm{OH}$ : Union Institute and University.

Kermit, P. (2001). Utviklingstrekk i tolkeprofesjonens yrkesetikk. Tolkeavisa: Medlemsblad av og for tolker tilknyttet Tolkeforbundet nr. 2.

Kermit P. (2004). Å ville hjelpe uten å være hjelper: Tolkers yrkesetikk i skjæringspunkt mellom anerkjennelse og dyktighet. Intern kompendium: Høgskolen i Sør-Trøndelag: Trondheim, Norge.

Kermit, P. (2006). "Tegnspråk og anerkjennelsen av døve som en språklig minoritet." I Jørgensen, S. R. og R. L. Anjum (Red.), Tegn som språk: En antologi om tegnspråk. Oslo: Gyldendal.

Lane, H. (2002). "Do Deaf People Have a Disability?" I Sign Language Studies 2:4 Summer 2002

http://dx.doi.org/10.1353/sls.2002.0019

Leneham, M., \& Napier, J. (2003). Sign language interpreters' codes of ethics: should we maintain the status quo? I G. Turner (Red.) Deaf worlds: international journal of deaf studies, Vol. 19, Issue 2, s. 78-98

Metzger, M. (1999). Sign language interpreting: deconstructing the myth of neutrality. Washington, D.C.: Gallaudet University Press.

Nilsen, A. B. (2011). Tolkemedierte samtaler - makt og avmakt i offentlig sektor. Norsk filosofisk tidsskrift Vol. 46, Nr. 1, s. 62-74. Universitetsforlaget.

Roy, C. B. (1993/2002). The problem with definitions, descriptions, and the role metaphors of interpreters. I F. Pöchhacker. \& M. Shlesinger (Red.), The interpreting studies reader (s. 345-353). London, England: Routledge.

Roy, C. B. (2000). Interpreting as a discourse process. New York, NY: Oxford University Press.

Shakespeare, T. (2006). The social model of disability. I L. J. Davis (Red.), The Disability Studies Reader. New York, NY: Routledge.

Skaten, I. (2012) "NAV vil utvide tolkerollen, med hvilke konsekvenser?" Døves tidsskrift $1 / 2012$, s. 16-17. Tilgjengelig på

http://www.deafnet.no/userfiles/documents/2012-01 DT.pdf .

Også publisert i Tolkeavisa, tilgjengelig på

www.tolkeforbundet.no/2012/05/nav-vil-utvide-tolkerollen-med-hvilke-konsekvenser 
Stadshaug, L., \& Foote, C. (2010). Opp med henda!: kommunikasjon på tospråklige arbeidsplasser. Oslo, Norge: Tolkeavdelingen ved Rycon AS.

Stokoe, W. C. (1960). Sign Language Structure: An Outline of the Visual Communication Systems of the American Deaf, i Studies in linguistics: Occasional papers (No. 8). Buffalo, NY: Dept. of Anthropology and Linguistics, University of Buffalo. Tilgjengelig på http://saveourdeafschools.org/stokoe_1960.pdf

Tate, G., \& Turner, G. H. (1997/2002). The code and the culture: sign language interpreting-in search of the new breed's ethics. I F. Pöchhacker \& M. Shlesinger (Red.), The interpreting studies reader (s. 373-383). London, England: Routledge.

Wadensjö, C. (1993/2002). The double role of a dialogue interpreter. I F. Pöchhacker \& M. Shlesinger (Red.), The interpreting studies reader (s. 355-370). London, England: Routledge.

Wadensjö, C. (1998). Interpreting as interaction. New York, NY: Addison Wesley Longman.

Woll, H. (Red.) (1999). Døvetolk-og Døvblindetolkyrkets Fremvekst i Norge. Bergen, Norge: Døves Forlag AS. 